MENGHIDUPI CIPTAAN ALLAH

Tanggung Jawab Manusia atas Ciptaan Allah Berdasarkan Mazmur 8

\title{
Jozef Hehanussa
}

\begin{abstract}
Psalm 8 is often interpreted as the psalmist's prayer of thanksgiving to the Lord. Then the Lord blessed him with human dignity by crowning him with glory and honor, and by making him to rule over the works of God's hands. The psalm actually did not deal with human responsibility towards God's creations directly. However, when psalmist spoke about power, it raises question of human dominion over other creatures. Even the phrase "put all things under his feet" could also give an impression, that man has a higher level than other creatures. Through this article, the author study and focus more on meaning of human power given by God related to human relationship with God and other creatures, especially with regard to human responsibility to other creatures. This reinterpretation of the meaning of power and crown has purpose on encouraging church institution and Christians to give more concern about nature and environment. Thus, churches and Christians can solve isues of environment which faced by people and other creatures today.
\end{abstract}

Keywords: Psalms, Genesis, power, creation, nature, church, global warming, greenhouse effect.

\begin{abstract}
Abstrak
Mazmur 8 lebih sering digambarkan sebagai doa syukur pemazmur kepada Tuhan yang telah membuat manusia menjadi ciptaan yang bermartabat karena dimahkotai dengan kemuliaan dan hormat serta diberi kuasa atas buatan tangan Allah. Mazmur ini tidak secara langsung bersinggungan dengan pertanggung jawaban manusia terhadap ciptaan Allah lainnya. Namun penyebutan kuasa dalam mazmur ini menimbulkan pertanyaan soal dominasi manusia atas ciptaan yang lain. Bahkan frase: Diletakkan di bawah kakinya" juga bisa memberi kesan bahwa manusia memiliki level yang lebih tinggi dari ciptaan yang lain. Melalui refleksi ini akan dikaji arti kuasa yang dimiliki manusia dalam hubungannya dengan relasi manusia dengan Tuhan dan juga dengan sesama, terutama berkaitan dengan tanggung jawab manusia kepada ciptaan yang lain. Memaknai kembali arti kuasa dan mahkota ini diharapkan dapat menolong gereja dan orang Kristen untuk lebih peduli lagi dengan persoalan-persoalan yang terjadi di sekitarnya terutama yang berhubungan dengan alam dan lingkungan.
\end{abstract}

Kata Kunci: Mazmur, Kejadian, kuasa, penciptaan, alam, gereja, pemanasan global, efek rumah kaca.

\section{PENDAHULUAN}

Secara sepintas Mazmur 8, khususnya ayat 6-9, tidak secara eksplisit menunjukkan hubungan antara teks ini dengan tanggung jawab manusia kepada 
ciptaan, apalagi soal penataan alam dan kesejahteraan hidup. Memang Mazmur 8 secara garis besar memperlihatkan kekaguman sang pemazmur terhadap karya Tuhan yang ditemuinya di dalam alam semesta, tetapi tidak berbicara tentang tanggung jawab manusia kepada alam. Meskipun demikian khotbah-khotbah yang mengacu pada teks ini memang sering menghubungkan teks ini dengan tanggung jawab manusia kepada alam atau ciptaan yang lain. Seorang pendeta dalam khotbahnya tentang teks Mazmur 8:6-9 bahkan membayangkan teks ini sebagai sebuah bentuk cerita tentang kisah penciptaan dalam versi pemazmur dan membandingkannya dengan kisah penciptaan dalam Kejadian 1. Marie Barth and Pareira lebih menghubungkan 'nyanyian untuk liturgi malam' ini dengan pengakuan akan eksistensi manusia yang menerima 'penghargaan' sebagai 'raja kecil' dari Tuhan. ${ }^{1}$ Clinton McCann lebih melihat Mazmur 8 sebagai sebuah bentuk doa (ucapan syukur), lebih dari sekadar nyanyian pujian, yang menekankan bukan hanya keagungan Tuhan tetapi juga status manusia yang dimuliakan oleh Allah. ${ }^{2}$ Theodore of Mopsuestia malah menghubungkan Mazmur ini dengan nubuat tentang Kristus (inkarnasi Kristus). ${ }^{3}$ Luther juga memiliki interpretasi yang sejalan dengan Theodore of Mopsuestia. Luther menafsirkan Mazmur 8 (dan juga Mazmur 16) sebagai nubuat tentang inkarnasi, kematian, kebangkitan dan kenaikan Kristus. ${ }^{4}$ Sementara Calvin menolak untuk menghubungkan secara langsung mazmur ini, khususnya ayat 5-9, dengan penyataan tentang Kristus, karena menurutnya ini memang terutama bicara tentang manusia. ${ }^{5}$ Waltke, Houston dan Moore juga mencatat bahwa Mazmur 8 ini diinterpretasi secara berbeda dari waktu ke waktu dan memperlihatkan pengaruh budaya dalam menginterpretasi Mazmur ini. ${ }^{6}$

Tulisan ini merupakan sebuahupaya untuk memahami Mazmur 8, khususnya ayat 6-9, dari sisi hubungan dan tanggung jawab manusia kepada ciptaan. Inilah yang membedakan pendekatan pemahaman yang dipakai penulis dengan kajiankajian sebelumnya. Kuasa merupakan salah satu istilah yang menonjol dalam Mazmur ini dan sering dimengerti lebih sebagai dominasi manusia atas ciptaan. Karena itu tulisan ini juga akan membahas pemaknaan atas kuasa ini dan bagaimana seharusnya kuasa ini diwujudkan dalam praktiknya, terutama ketika dihubungkan dengan persoalan-persoalan lingkungan yang dihadapi manusia saat ini. Persoalan pemanasan global yang dihadapi dunia saat ini memang seharusnya mendorong manusia untuk menginterpretasi kembali bagaimana dia berelasi dengan alam. 


\section{MAZMUR 8: ALLAH TETAP YANG UTAMA}

Ada dua figur sentral yang mendapat perhatian dalam Mazmur ini, yaitu Tuhan sebagai Pencipta, dan manusia, yang dibuat hampir sama seperti Allah dan telah dimahkotai dengan kemuliaan dan hormat. Namun figur yang utama dan terutama di sini adalah Sang Pencipta itu sendiri yang hendak dimuliakan melalui Mazmur ini. Kesamaan bagian pembuka dan penutup dari Mazmur ini memperlihatkan bahwa yang ingin ditonjolkan di sini adalah 'Dia yang Agung' yang keagungannya itu nyata melalui karyanya, khususnya melalui manusia. Sementara itu manusia dalam Mazmur ini menjadi figur yang menyadari bahwa kemuliaan dan hormat yang dimilikinya hanya merupakan sebuah anugerah dari Sang pencipta. Karena itu kemuliaan dan kehormatan manusia tidak bisa disetarakan dengan keagungan dan kemuliaan Sang Pencipta. Dengan demikian pemahaman terhadap Mazmur ini jangan sampai memindahkan fokus dari Sang Pencipta kepada manusia. Catatan ini mengingat pembacaan sepintas terhadap Mazmur 8:6-9 akan memberi kesan bahwa fokusnya adalah pada manusia dengan segala keistimewaannya sebagai ciptaan Allah (Mazmur 8:6).

Menurut saya Mazmur 8:5 pada satu sisi merefleksikan peristiwa penciptaan manusia, di mana manusia dijadikan serupa dan segambar dengan Allah (Kejadian 1:26, 3:22a), tetapi di sisi lain juga mencerminkan keterbatasan manusia yang berhubungan dengan pelanggaran yang dilakukannya (Kejadian 3:22b). Dalam konteks inilah kita ditolong untuk memahami kesadaran pemazmur bahwa manusia itu dijadikan tidak sama seperti Allah (seperti pembahasaan Kejadian 1:26) tetapi 'hampir sama seperti Allah'. Di samping itu, sekalipun Mazmur 8 memberi kesan adanyasebuah 'level atau derajat kehormatan'yang berhubungan dengan Sang Pencipta dan ciptaannya - level tertinggi: Tuhan, Sang Pencipta yang Agung; level menengah: manusia yang dibuat sama seperti Allah dan dimahkotai dengan kemuliaan dan hormat; level bawah: buatan tangan Allah yang berada dalam kuasa manusia $^{7}$ dan memberikan perhatian pada manusia yang menurutnya dibuat hampir sama seperti Allah, namun tetap saja tidak berarti mengalihkan penghormatan utama dari Sang Pencipta kepada manusia. Manusia justru memainkan peran sebagai yang mengakui akan keagungan Tuhan dan bersyukur atas 'penghargaan' yang diberikan Tuhan kepadanya dengan menjadikannya sebuah karya terbaik, sebagaimana diinterpretasi oleh Athanasius, bapa gereja. ${ }^{8}$ Keadaan ini menunjukkan bahwa Allah 
tetap menjadi yang sentral dalam 'lagu' pemazmur, tanpa maksud ikut menonjolkan keberadaan manusia.

Calvin bahkan menegaskan bahwa Mazmur ini bukan ingin menonjolkan status manusia yang lebih tinggi dari ciptaan yang lain yang dalam kenyataan tidak lebih hebat dari cipataan lain yang ada dalam kuasanya. Interpretasi ini muncul karena bagi Calvin Mazmur ini bertujuan untuk menghibur mereka (baca: orangorang Yahudi) yang tak berdaya karena berada di bawah kuasa orang-orang yang mencerai-beraikan mereka dan memperlakukan mereka dengan tidak adil. ${ }^{9}$ Karena itu Mazmur ini juga menjadi sebuah penghiburan dan penguatan kepada orang-orang Yahudi tersebut, bahwa mereka masih tetap memiliki Allah yang Agung yang bahkan bisa memperlihatkan kekuatanNya melalui bayi-bayi dan anak-anak yang cenderung dianggap lemahuntuk mengalahkan para musuh dan pendendam (ayat 2).Karena itu sudah seharusnya mereka selalu ingat kepada Allah mereka dan mengucap syukur kepadaNya.

Allah bukan hanya menyelamatkan manusia, dia bahkan memahkotai (dari akar kata 'atarah' [Ibrani] = mahkota) manusia dengan kemuliaan dan hormat (ayat 5), yang mana tindakan ini menunjuk kepada sebuah posisi penting yang dimiliki manusia. Tetapi dalam tradisi kerajaan, pemberian mahkota bukan hanya menunjuk kepada sebuah kedudukan penting dari penerima mahkota, tetapi juga tanggung jawab yang harus dilakukan oleh sang penerima mahkota.Seseorang yang dimahkotai tidak berarti bahwa dia bisa bertindak sesuka hatinya. Sebaliknya dia harus bertindak sesuai dengan kehendak Allah agar kemuliaan dan kehormatan yang diterimanya terpancar jelas melalui karyanya. Saul yang dimahkotai sebagai raja pada akhirnya ditolak karena dia tidak melakukan apa yang diperintahkan Tuhan kepadanya (1 Samuel 15:1-35). Daud yang dimahkotai sebagai raja juga dihukum oleh Allah karena melakukan yang jahat kepada hambanya, Uria (2 Samuel 11:112:25). Ini menunjukkan bahwa manusia yang dimahkotai dengan kemuliaan dan hormat oleh Allah bukan saja menerima sebuah posisi penting tetapi juga tanggung jawab penting untuk selalu melakukan apa yang dikehendaki Allah kepadanya. Itu artinya bahwa sepanjang hidupnya manusia yang dimahkotai harus mampu memperlihatkan Allah yang memahkotainya. Jika ayat ini secara khusus dihubungkan dengan Daud, dimana dimahkotai dengan kemuliaan dan hormat menunjuk kepada pengangkatan Daud sebagai raja, maka kisah kehidupan Daud 
dalam Alkitab menunjukkan bagaimana Daud berusaha untuk hidup selalu berkenan kepada Tuhan. Ada masa dimana Daud melakukan kesalahan (lih. 2 Samuel 11:127) tetapi selalu ada upaya dari Daud untuk menyadari kesalahannya dan kembali hidup berkenan di hadapan Tuhan (lih. 2 Samuel 12:1-25)

\section{MANUSIA TETAPLAH MANUSIA, BUKAN ALLAH}

Dalam membaca Mazmur 8, bila kita mengalihkan perhatian dan penekanan dari Tuhan kepada manusia maka frasa 'hampir sama seperti Allah' dan berkuasa atas buatan tanganMu' (ayat 6) akan menjadi lebih menonjol dan semakin mempertegas dominasi manusia atas ciptaan yang lain. Dalam interpretasinya terhadap Mazmur 8, Johan H. Coetzee memperlihatkan bahwa frasa 'membuatnya hampir sama seperti Allah' sebetulnya tidak perlu dicari di luar teks (misalnya menghubungkannya dengan Kisah penciptaan manusia dalam Kejadian), karena diekspresikan oleh pemazmur secara tidak langsung dalam mazmur ini. Interpretasi ini muncul ketika Coetzee membandingkan ayat 2 dan ayat 6-8. Ke-hampir-sama-an ini tampak melalui kuasa Allah dan manusia atas yang lain. Jika dalam ayat 2 Allah berkuasa atas musuh dan pendendam melalui mereka yang dianggap lemah (bayi dan anak-anak), dalam ayat 6-8 manusia berkuasa atas binatang-binatang. Coetzee bahkan memperkuat kesannya dengan mengatakan bahwa frasa 'diletakkan dibawah kakinya' memberi kesan seakan-akan binatang-binatang tersebut adalah musuh manusia. ${ }^{10}$ Jadi bukan hanya Allah yang berhadapan dengan musuh, tetapi manusia juga berhadapan dengan musuhnya. Di sinilah kemiripannya. ${ }^{11}$ Interpretasi Coetzee ini dapat dimengerti sebagai sebuah peringatan bagi kita yang membaca Mazmur 8 ini dengan menekankan martabat manusia.

Menurut saya pendekatan Calvin sebagaimana yang sudah dipaparkan sebelumnya bisa dipakai untuk mereduksi upaya menonjolkan manusia sebagai yang memiliki kuasa atas ciptaan yang lain. Untuk itu sebelum kita membaca Mazmur ini sebagai nyanyian syukur kepada Allah karena apa yang dilakukannya kepada manusia, sebagaimana interpretasi yang dibuat oleh Erhard Gerstenberger, kita bisa lebih memberi perhatian pada pertolongan yang dibutuhkan manusia (Calvin: orangorang Yahudi) dalam menghadapi orang-orang yang memusuhi dan memiliki dendam kepada mereka. Interpretasi Gesternberger dihubungkan dengan manusia berada dalam situasi tertekan karena penindasan yang mereka alami tetapi tidak ada 
yang dapat menolong mereka menghadapi para penindas itu. ${ }^{12}$ Pertolongan ini pada akhirnya mereka temukan pada Allah, yang bahkan dengan kuasa yang dimilikinya mampu menaklukkan para penindas itu melalui bayi-bayi dan anak-anak yang menyusu.Jadi frasa 'Engkau mengingatnya' dan 'Engkau mengindahkannya' berhubungan dengan pertolongan Allah sebagaimana disebutkan dalam ayat 2 . Dengan demikian ingin diperlihatkan bahwa kuasa yang dimiliki manusia tidak membuat dia betul-betul berkuasa. Dia juga bisa tampak lemah dan tak berdaya ketika berhadapan dengan kausa yang lain. Kemuliaan dan kehormatan yang terimanya bukan berhubungan dengan kuasa yang dimilikinya tetapi berhubungan dengan pertolongan yang diterimanya ketika dia tidak berdaya. Jadi jika manusia yang memiliki kuasa saja bisa berada dalam situasi yang lemah dan membutuhkan pertolongan dari Tuhan, maka manusia perlu juga peka terhadap 'suara ciptaan yang lain'. Janganlah ketika manusia tidak mampu berhadapan dengan kekuatan yang lain dia memakai kuasa yang dimilikinya untuk menekan ciptaan yang lain. Catatan ini mengingatkan kita pada perilaku seorang hamba yang diceritakan Yesus dalam Matius 18:23-35, yang menerima pertolongan di tengah ketidakberdayaan tetapi memakai 'kuasa' yang dimilikiuntuk menekan yang lain.

Kita harus menghindari diri dari membaca Mazmur 8 dengan pendekatanpendekatan pemahaman yang cenderung menonjolkan martabat manusia sebagai yang lebih tinggi dari yang lain dan menganggap ciptaan yang lain sebagai rendah martabatnya dari manusia dan karena itu manusia tidak perlu menjaga sikapnya terhadap ciptaan yang lain. Manusia tetaplah manusia, bukan Allah, karena kuasa yang dimilikinya tetaplah terbatas. Sekalipun dalam ayat 6 dikatakan bahwa: "Engkau membuat dia berkuasa atas buatan tangan-Mu; segala-galanya telah Kauletakkan di bawah kakinya", namun kuasa itu terbatas hanya terbatas pada binatang (ayat 7-8), bukan pada seluruh ciptaan Allah. Ayat ini sekaligus memperlihatkan perbedaan dan persamaan antar Mazmur 8 dengan Kejadian 2:1516 berkaitan dengan pemberian kuasa atau mandat. Persamaannya adalah bahwa kuasa atau mandat yang diterimanya sama-sama terbatas, bukan kepada seluruh ciptaan. Perbedaannya adalah Mazmur memberi penekanan pada kuasa (Ibrani: tamshilehu (dari akar kata mashal), menunjuk kepada sebuah otoritas yang berwujud dalam situasi memerintah, mengontrol), sedangkan Kejadian memberi penekanan pada mengusahakan dan memelihara (Ibrani: le'avedah - dari akar kata abad - yang 
bukan hanya menunjuk tindakan kultivasi (bercocok tanam) tetapi juga menunjuk kepada sikap sebagai seorang pelayan; dan uleshamerah - dari akar kata shamar yang menunjuk kepada tindakan menunggui, menjaga, melindungi, memberi perhatian, merawat). Perbedaan yang lain adalah mazmur membatasi kuasa itu pada binatang sedangkan Kejadian membatasinya pada tanaman atau taman. ${ }^{13}$ Jadi baik Mazmur 8 maupun Kejadian 2 sama-sama memperlihatkan bahwa kuasa yang ada dimiliki manusia terbatas.

Berkaitan dengan penyebutan 'kaki' dalam ayat 6 , menurut saya, istilah ini lebih tepat menyimbolkan kuasa atau kontrol, daripada diartikan sebagai penaklukan. Frase 'di bawah kakinya' tidak bisa hanya diterjemahkan semata-mata sebagai dominasi manusia atas binatang. Dalam realitas kehidupan, manusia juga sering 'takluk' kepada binatang, bahkan juga bisa menjadi korban binatang. Lagi pula binatang-binatang yang disebutkan dalam ayat 7-8 menunjuk kepada binatangbinatang yang 'dibutuhkan' manusia di dalam hidupnya. Karena itu frase ini menunjukkan bahwa manusia memiliki kuasa atas binatang-binatang tersebut untuk melindungi dan mengelola mereka demi kebaikan hidup manusia. Gambaran ini juga memperlihatkan suatu era di mana binatang mempunyai tempat penting dalam kehidupan manusia. Saya setuju dengan apa yang dikemukakan Othmar Kiel, bahwa pemberian kuasa dalam Mazmur 8:6 tidak harus diartikan sebagai keinginan sesuka hati menaklukkan binatang-binatang tersebut. Mazmur 8:6-8 ini harus lebih diartikan sebagai tugas manusia untuk melindungi binatang-binatang ternak atau yang hidup di sekitarnya (domestic animals). Penafsiran Kiel ini dihubungkan dengan penggambaran yang sama di Asyur. Dalam sebuah segel berbentuk silinder yang berasal dari Asyur Baru (sekarang Irak) dari periode 9-7 seb.M ada gambar kaki yang diletakkan di atas binatang yang lemah. Jika simbol ini dihubungkan dengan raja maka meletakkan kaki di atas binatang yang lemah ini tidak hanya menunjuk kepada dominasi tetapi juga menunjuk kepada perlindungan kepada binatang yang lemah dari serang binatang yang kuat seperti singa. ${ }^{14}$ Pemaknaan yang mirip terhadap kaki juga dapat ditemukan di Mesir. Pada era Dinasti ke-18 di Mesir, frase " $h r \underline{t} b(w) t / \underline{t b t y}$ ', "under the sandals" (berhubungan dengan kaki), dikaitkan dengan keberadaan Firaun sebagai pelindung bagi Mesir. ${ }^{15}$ Jika Mazmur 8:6 dihubungkan dengan konteks Daud, secara khusus dengan Daud sendiri, maka dapat diartikan bahwa kuasa yang dimiliki Daud bukan hanya sebagai raja untuk 
melindung 'manusia Israel', tetapi juga untuk melindungi semua binatang yang ada dilingkungannya.

Sebagaimana sudah dikemukakan pada bagian sebelumnya, terkait dengan frasa 'dimahkotai dengan kemuliaan dan hormat', pemberian kuasa kepada manusia atas buatan tangan Allah memang bukan berarti mengesampingkan keberadaan Allah sebagai pencipta dan sekaligus pemilik ciptaan. Pemberian kuasa kepada manusia tidak bisa dimengerti terpisah dari 'membuatmanusia hampir sama seperti Allah'. Artinya bahwa jika Allah yang mencipta dan menjadi pemilik ciptaannya begitu mencintai dan peduli kepada ciptaannya (band. Mazmur 145:9-10) ${ }^{16}$, maka manusia yang dibuat hampir sama dengan Allah juga harus memiliki 'rasa' yang (hampir) sama kepada buatan tangan Allah. DeClaissé-Walford, Jacobson dan Tanner menggambarkan Mazmur ini sebagai pujian kepada Allah sebagai raja dari semua ciptaan, sementara pemberian kuasa kepada manusia merupakan peneguhan keberadaan manusia sebagai anggota kerajaan. Sebagai anggota kerajaan yang juga memiliki kuasa sudah seharusnya manusia bukan hanya berkuasa tetapi juga memiliki rasa tanggung jawab kepada ciptaan sebagai tanda baktinya kepada Allah, raja semua ciptaan. ${ }^{17}$

Pemberian kuasa juga tidak bertujuan untuk mengukuhkan manusia yang tadinya lemah dan tidak berdaya dan membutuhkan pertolongan Tuhan (ayat 2) menjadi manusia yang digdaya dan mengesampingkan apa yang menjadi kehendak Allah bagi manusia. Menurut saya bagian penutup dari Mazmur 8 ini secara tidak langsung memperlihatkan kesadaran pemazmur bahwa pemberian kuasa atas buatan tangan bukan berarti meniadakan kemuliaan (nama) Tuhan. Karena itu doa syukur pemazmur ini diakhiri dengan "betapa mulianya nama-Mu di seluruh bumi". ${ }^{18}$ Kemuliaan nama Tuhan di seluruh bumi tentu saja memiliki keterkaitan dengan keberadaan semua ciptaan Tuhan di muka bumi.Sulit membayangkan bahwa manusia bisa memuliakan nama Tuhan dengan menyalahgunakan kekuasaan yang diberikan Tuhan kepadanya atas semua ciptaan. Itu artinya bahwa dalam menjalankan kuasanya atas buatan tangan Tuhan manusia harus bisa menunjukkan bahwa kuasa itu memang pantas diberikan kepadanya dan bahwa dia pun pantas dimahkotai dengan kemuliaan dan hormat. 


\section{KUASA YANG MENGHIDUPI}

Film Duma dapat menjadi bahan refleksi tentang relasi manusia dengan yang lain. Ketika menulis paper ini, saya sempat menyelinginya dengan menonton film 'Duma' yang berkisah tentang persahabatan seorang anak remaja yang bernama Xana dengan seekor $\operatorname{citah}^{19}$. Film ini bercerita tentang seekor citah yang masih kecil yang ditinggal mati oleh ibunya karena dibunuh seekor singa. Citah ini kemudian dipelihara oleh Xan dan ayahnya, Peter. Ketika citah, yang kemudian diberi nama Duma, bertambah besar, Peter mengingatkan Xan agar mengembalikan Duma ke rumahnya yang sebenarnya. Bagi Peter, Duma hanya bisa benar-benar hidup jika dia hidup di habitatnya. Menunggu sampai Duma tua baru mengembalikannya ke habitatnya tidak baik bagi Duma untuk bertahan hidup di habitatnya. Namun ketika ayahnya meninggal dunia, rencana untuk mengembalikan Duma ke habitatnya tertunda. Bagi Xan, Duma adalah sahabat, tetapi bagi orang lain, seperti bibinya dan teman-teman di sekolahnya, Duma adalah hewan yang menakutkan. Xan mulai menyadari bahwa dia berhadapan dengan masalah ketika Duma bisa keluar dari rumahnya dan pergi ke sekolahnya. Xan bahkan kemudian harus membawa Duma pergi meninggalkan kota agar Duma tidak ditangkap. Dalam pelariannya Xan ingat kepada pesan ayahnya untuk mengembalikan Duma ke dunianya. Karena sekalipun Xan bisa membuat Duma menjadi sahabatnya, Duma harus hidup dalam 'ke-liarannya' dan 'kebuasan'-nya. Pada akhirnya Xan berhasil membawa Duma kembali ke habitatnya. Duma berhasil menemukan temannya bahkan tanpa diajari bisa menunjukkan 'ke-liar-annya' dan 'kebuasan'-nya, yang menurut Peter hidup di dalam tulang dan darahnya bagaikan sebuah memori. Meskipun demikian sebelum mereka berpisah, Duma juga menunjukkan bagaimana cinta dan perhatiannya kepada Xan.

Menurut saya film ini dapat sedikit menolong kita memahami apa yang ingin dikatakan pemazmur tentang kuasa manusia atas buatan tangan Allah, khususnya binatang dan bagaimana manusia membangun relasi dengan mereka yang diletakkan di bawah kakinya. Menggunakan bahasa Mazmur 8, film ini menunjukkan bahwa sekalipun Xan (baca: manusia) berhasil 'menguasai' Duma yang secara naluri adalah binatang liar dan buasa, namun dia tidak bisa terus-menerus berada dalam kontrolnya untuk kesenangannya saja. Sebagaimana yang dikatakan Peter, ayahnya, akan lebih baik jika Xan membawa pulang Duma ke habitatnya untuk menghidupi hidupnya sendiri. Menjadi yang berkuasa atas Duma (baca: binatang atau ciptaan 
lainnya) bukan berarti menjauhkan mereka dari dunianya untuk kepentingan manusia semata. Sebaliknya menjadi yang berkuasa atas binatang atau ciptaan yang lain berarti memiliki tanggung jawab untuk membuat mereka menghidupi hidup mereka. Tidak mudah untuk melakukan hal itu tetapi itu harus diupayakan karena menjadi bagian dari pemenuhan kuasa yang diterima manusia.

Pembahasan Mazmur 8 ini memperlihatkan kepada kita bahwa di satu sisi ada pujian dan doa syukur atas keagungan Allah, tetapi di sisi lain memunculkan kesadaran akan besarnya tanggung jawab yang diterima manusia.Mazmur ini memberikan beberapa nilai penting bagi gereja di dalam menjalankan tanggung jawabnya terutama tanggung jawabnya terhadap ciptaan Allah lainnya.

1. Mahkota dan kuasa itu milik Allah yang diberikan kepada manusia. Karena itu dalam menjalankan kuasanya manusia jangan hanya berorientasi pada mahkota dan kuasa. Ketika manusia hanya berorientasi pada mahkota dan kuasa maka dia akan cenderung mengesampingkan keberadaan Tuhan dan bertindak seakanakan mahkota dan kuasa itu miliknya sendiri, bahkan tidak ada yang dapat mengambil mahkota dan kuasa itu dari dirinya sendiri. Bagi gereja pertanyaan yang mendasar adalah: apakah dalam gereja dalam menjalankan kuasanya secara praksis lebih mengedepankan Allah dan membuat manusia dan juga buatan tangan Allah lainnya mengucap syukur dan memuliakan Allah atau hanya lebih mengedepankan gereja itu sendiri dan tidak mendatangkan sukacita bagi yang lain?Sejarah gereja menunjukkan bahwa gereja juga bisa salah dalam menggunakan kuasa yang diberikan kepadanya. Dengan kuasa yang dimilikinya gereja membuat dirinya menjadi begitu lebih penting dibandingkan Allah yang memberikan kuasa itu. Dalam perjalanan sejarahnya gereja pernah menggantikan kalimat Yesus: "Tidak ada seorangpun yang datang kepada Bapa, kalau tidak melalui Aku" menjadi "Tidak ada seorangpun yang datang kepada Bapa, kalau tidak melalui gereja". Kesannya adalah Yesus yang menjadi jalan kebenaran dan hidupnya diganti oleh gereja sebagai jalan kebenaran dan hidup. Karena itu Mazmur ini selalu mengingatkan gereja, terutama para pemimpin gereja, untuk hanya mengedepankan Allah dalam menggunakan kuasa yang diberikan kepadanya. Karena itu membangun tanggung jawab gereja kepada ciptaan harus dimulai dari merefleksikan kembali kuasa yang dimiliki oleh gereja. Karena itu kebijakan-kebijakan atau keputusan-keputusan yang dibuat oleh gereja, sebagai 
wujud konkret dari kuasa yang dimilikinya, haruslah sungguh-sungguh memuliakan Allah sang pemberi kuasa itu dan untuk kepentingan memuliakan Allah, bukan untuk kepentingan gereja.

2. Sebagaimana ketika manusia berada dalam ketidakberdayaan Allah telah menolongnya, mengangkatnya dari ketidakberdayaan itu, maka kuasa yang diberikan Allah kepada manusia harus juga dipakai untuk menolong buatan tangan Allah yang lain untuk keluar dari ketidakberdayaannya. Janganlah kuasa yang diberikan Allah dipakai manusia (baca: gereja) untuk menekan yang lain yang tidak berdaya. Gereja jangan hanya mengritik orang lain (baca: pemimpin dunia) yang menyalahgunakan kuasa yang mereka miliki, sementara gereja juga sendiri sering menyalahgunakan kuasa yang dimiliki gereja untuk 'menekan' yang lemah.Sejarah gereja mencatat bahwa gereja pernah salah dalam menggunakan kuasa yang dimilikinya, misalnya ketika gereja (baca: pemimpin gereja) menghukum John Wycliff dan John Huss karena berbeda pendapat dengan gereja dan menginginkan reformasi dalam tubuh gereja. Dalam beberapa konflik yang terjadi dalam gereja, gereja juga cenderung menggunakan kuasanya untuk 'menyingkirkan' mereka yang berbeda pendapat dengan gereja. Gereja harus menggunakan kuasa yang dimilikinya untuk menolong yang lain, bukan untuk menekan yang lain.Itu artinya bahwa gereja harus mampu menggunakan kuasa yang dimilikinya secara adil demi kelangsungan hidup sejahtera bersama, baik gereja maupun yang lain. Dalam hubungannya dengan alam, gereja juga bisa menata alam dengan adil jika gereja mampu pertama-tama mengendalikan kuasa yang dimilikinya untuk menghadirkan kebaikan bagi alam.

Dalam hubungannya dengan kuasa dan yang lain (baca: kelompok periferi),

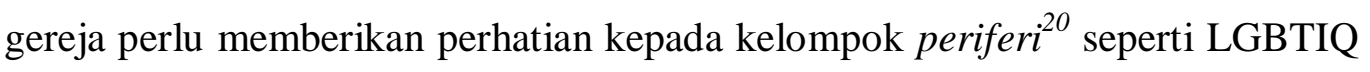
(Lesbian, Gay, Bisexual, Transgender, Intersex dan Queer/Questioning), korban HIV-AIDS dan korban-korban kekerasan dalam rumah tangga (KDRT). Cara gereja menilai kelompok ini dengan menggunakan dogma-dogma gereja dan nilai-nilai dogmatis kekristenan membuat mereka sering diperlakukan dengan tidak adil. Sering lebih mudah bagi gereja untuk menggunakan kuasa atas mereka dengancara menghakimi mereka, dibandingkan dengan merangkul dan memberi tempat bagi mereka di dalam gereja dan mendorong mereka untuk tidak perlu takut menunjukkan eksistensi mereka. Sudah saatnya bagi gereja 
merubah cara pandangnya dengan hanya melihat kelompok ini dari kacamata masalah. Sudah saatnya bagi gereja untuk memikirkan juga hak-hak mereka dalam gereja, karena ini berhubungan bukan hanya dengan persoalan orientasi seksual tetapi juga identitas gender dan hak hidup.Dengan kuasanya gereja harus mampu menolong mereka keluar dari 'ketidakberdayan' mereka yang sering lebih disebabkan oleh konstruksi sosial, baik yang dibangun oleh masyarakat maupun oleh gereja.

3. Mengubah paradigma 'menguasai' kepada 'melindungi' dalam relasi manusia dengan ciptaan yang lain adalah cara tepat dalam mewujudkan kebaikan hidup bagi manusia dan juga ciptaan yang lain. Bagi gereja, ini hanya bisa terwujud jika orientasi pelayanan gereja terutama dalam menggunakan kuasa yang dimilikinya tidak hanya ke dalam atau untuk kepentingan gereja sendiri tetapi juga untuk kepentingan yang lain, termasuk alam dan lingkungan. Manusia saat ini sering diperhadapkan dengan bencana alam yang juga disebabkan oleh kesalahan manusia dalam menggunakan kuasa yang dimilikinya, seperti bencana asap di Sumatera dan juga banjir yang disebabkan oleh penebangan hutan oleh para pemilik HPH. Karena itu tanggung jawab gereja untuk selalu mengingatkan manusia untuk tidak hanya mengartikan kuasa yang dimilikinya sebagai dominasi atas alam dan lingkungan tetapi juga untuk merawatnya. Gereja harus lebih banyak membuat program-program yang bertujuan merawat dan melestarikan alam dan lingkungannya, terutama gereja yang masyarakatnya sering berhadapan dengan bencana alam, seperti banjir, tanah longsor, kebakaran hutan dan lainnya. Belajar dari film Duma, gereja harus mendorong manusia (baca: warga gereja) untuk menolong ciptaan yang lain menghidupi kehidupannya. Di kompleks Lembaga Pembinaan dan Pengaderan Sinode (LPPS) milik Sinode Gereja-Gereja Kristen Jawa dan Gereja Kristen Indonesia Sinode Wilayah Jawa Tengah, di mana saya tinggal, setiap hari kami bisa mendengar suara kicauan merdu beraneka burung yang bertengger di pohonpohon di kompleks LPPS. Untuk melindungi burung-burung ini dari keinginan orang-orang yang ingin menyangkarkannya pengurus LPPS menempelkan beberapa peringatan dan larangan untuk memburu burung di sekitar kompleks LPSS. Setiap warga LPPS akan mengingatkan siapa saja yang berupaya untuk menangkap burung-burung tersebut. Beberapa kali saya menyingkirkan dan 
membuang sangkar burung kosong yang berisikan umpan yang secara diamdiam diletakkan di pohon-pohon di kompleks LPPS untuk menangkap burungburung yang ada.

Ini hanya contoh kecil dari bagaimana menggunakan kuasa untuk menolong ciptaan yang lain menghidupi kehidupannya. Penghijauan lingkungan dan tanahtanah yang gundul atau juga proyek-proyek konservasi flora dan fauna merupakan upaya-upaya penting dalam menjaga keseimbangan alam. Berkurangnya air tanah dan krisis air bersih yang saat ini dihadapi manusia juga berhubungan dengan kesalahan manusia dalam menggunakan kuasa yang dimilikinya. Kawasan penyerapan dan perlindungan air tanah diganti oleh bangunan-bangunan yang lebih banyak mengekspresikan egoisme konsumerisme manusia, seperti hotel, mall, apartemen dan sebagainya. Karena itu gereja terpanggil untuk mendorong orang bukan hanya membuat bangunan-bangunan yang menjadi kebutuhannya tetapi juga harus menyediakan ruang untuk penyerapan air dan perlindungan air tanah. Gereja juga dalam mendirikan bangunan gereja atau bangunan lain pendukung aktivitas gereja juga harus memikirkan ketersediaan ruang untuk penyerapan air dan perlindungan air tanah. Di samping itu gereja harus mendorong masyarakat (baca: warga gereja) untuk lebih bijaksana dalam menggunakan air yang tersedia.

Masalah lain yang dihadapi umat manusia saat ini, termasuk gereja, adalah pemanasan global yang berkaitan dengan efek rumah $\mathrm{kaca}^{21}$. Beberapa penyebab efek rumah kaca adalah: [a] kebakaran hutan, yang mana ketika pohon-pohon terbakar maka $\mathrm{CO} 2$ yang tersimpan di dalam akan dikeluarkan ke atmosfer; [b] erupsi gunung berapi yang menghasilkan jumlah besar dari $\mathrm{CO} 2$; [c] pohon, tanaman, rumput dan vegetasi (tumbuh-tumbuhan) lainnya yang ketika mati gas yang dilepaskannya ke atmosfer setengah darinya adalah $\mathrm{CO}$ dan begitu pula bagian lain dari karbon ini diserap tanah dan pada waktunya dilepaskan ke atmosfer; [d] uap air yang naik kepermukaan bumi adalah penyumbang $65 \%$ efek rumah kaca; [f] hewan seperti sapi, domba, kambing, unta dan bison yang menghasilkan zat metana melalui cara mereka mencerna makanan, terutama ketika mereka bersendawa; [g] padi yang ditanam di rawa-rawa atau tanah bergenang air juga menghasilkan metana yang menyebabkan efek rumah kaca; [h] pembuangan kotoran manusia dan hewan di pabrik pengolahan limbah, 
knalpot mobil juga menghasilkan Nitrous Oxide (NO2). ${ }^{22}$ Menghadapi situasi ini, gereja bisa mendorong masyarakat (baca: warga gereja) untuk melakukan beberapa hal mudah, yaitu: merawat tumbuhan agar tetap tumbuh, hijau dan segar, tidak membiarkan pohon ditebang dengan sembarangan, menggalakkan penghijauan, mengurangi konsumsi daging, mengonsumsi makan yang masih segar, mengurangi pemakaian kantong plastik, menghancurkan atau membakar barang sulit untuk didaur ulang, tidak menggunakan air condition(AC) dengan suhu yang rendah, matikan lampu jika tidak memakinya dan gunakan lampu hemat energi, jangan biarkan air terbuang percuma, cabut kabel charger telepon seluler dan alat elektronik lainnya setelah dipakai dan masih banyak hal lain yang bisa dilakukan. ${ }^{23}$

Gereja juga perlu memperhatikan aktivitas-aktivitasnya, terutama dalam ibadah, yang menunjukkan ketidakbersahabatan gereja dengan alam. Pemanfaat kertas yang begitu banyak untuk liturgi dan informasi atau warta gereja yang kemudian dibuang atau ditinggalkan begitu saja oleh warga gereja, atau juga penggunaan kertas yang begitu banyak dalam persidangan-persidangan gereja memperlihatkan bahwa gereja masih belum mendukung upaya go green. Berapa banyak lagi pohon yang akan ditebang untuk mencukupi kebutuhan gereja ini? Gereja harus belajar untuk menggunakan material-material daur ulang, termasuk kertas yang bisa di daur ulang untuk kebutuhan gereja atau mencari cara yang lebih mendukung pelestarian alam tanpa mengurangi efektivitas pelayanan gereja. Ibadah-ibadah yang lebih banyak menghabiskan energi juga perlu dipertimbangkan. Karena itu sudah saatnya gereja memikirkan penggunaanpenggunaan energi alternatif dalam mendukung pelayanan gereja.

Hal lain yang bisa dilakukan gereja dalam menyikapi penggunaan kuasa untuk menata alam bagi kesejahteraan bersama adalah menyikapi kebijakan-kebijakan pemerintah yang tidak berpihak pada pelestarian ciptaan. Undang-Undang Dasar 1945 (yang telah diamandemen) pasal 33 ayat 3 berbunyi: "Bumi dan air dan kekayaan alam yang terkandung di dalamnya dikuasai oleh negara dan dipergunakan untuk sebesar-besarnya kemakmuran rakyat. Namun di dalam pelaksanaannya penggunaan bumi dan air serta kekayaan alam ini lebih banyak menguntungkan pemilik modal atau para investor. Mayoritas rakyat, terutama mereka yang berdekatan dengan sumber-sumber kekayaan bangsa itu, seperti di 
Papua, hanya merasakan sebagai kecil dari pengusahaan kekayaan alam tersebut. Yang lebih parah lagi adalah pengusahaan kekayaan alam ini tidak diikuti oleh perawatan alam. Di berbagai daerah pertambangan seperti di Papua dan Kalimantan kita akan menemukan kawah-kawah atau lubang-lubang besar hasil eksplorasi kekayaan alam yang kemudian ditinggalkan begitu saja setelah kekayaan alamnya telah dikeruk. Gereja diharapkan bisa lebih kritis lagi dalam menyuarakan ketidakadilan semacam ini dan juga penerapan-penerapan kebijakan pemerintah yang hanya menggunakan paradigma kuasa sebagai bentuk dominasi dan mengabaikan sisi perawatan atau menghidupi kehidupan.

\section{PENUTUP}

Interpretasi dan pembahasan saya atas Mazmur 8 ini dengan tegas ingin memperlihatkan bahwa kuasa yang diterima manusia harus berhulu dan bermuara pada keagungan dan mengagungkan Allah. Pemazmur sendiri sadar bahwa keagungan Allah mengatasi langit (ayat 1). Itu berarti lebih dari manusia dan kuasa yang diberikan Allah kepadanya. Sehingga seperti yang telah dikemukakan sebelumnya, dalam menjalankan kuasanya atas buatan tangan Allah, manusia harus memberi ruang bagi manusia sendiri dan juga buatan tangan Allah lainnya untuk melihat keagungan Allah dan memuliakan Allah. Manusia seharusnya menyadari bahwa sebelum dia dimahkotai dengan kemuliaan dan hormat serta menerima kuasanya, manusia yang lemah (the oppressed) ditolong oleh Allah dari ketidakberdayaannya. Dan ketika Allah memberikannya kuasa atas buatan tangan Allah dan meletakkan semuanya di bawah kakinya, itu tidak bertujuan untuk menjadikan manusia sebagai penindas (oppressor) bagi yang lain yang tidak memiliki kuasa seperti manusia. Karena itu ketika menjalankan kuasa yang dimilikinya manusia harus bisa menolong buatan tangan Allah lainnya untuk menghidupi hidupnya. Sebagaimana yang sudah dikemukakan dalam bagian sebelumnya, terutama berkaitan dengan persoalan lingkungan (baca: pemanasan global) Banyak hal bisa dilakukan manusia (baca: gereja) dengan kuasa yang dimilikinya untuk kembali memperbaiki dan menata alam ini agar melalui alam ini kemuliaan dan keagungan Tuhan dapat dirasakan dan dinyanyikan. 


\section{CatatanAkhir}

1 Marie Claire Barth dan B. A. Pareira, Kitab Mazmur 1-72. Pembimbing dan Tafsirannya. (Jakarta: BPK Gunung Mulia, 2009), h. 170, 174-175

${ }^{2}$ J. Clinton McCann Jr. Great Psalms of the Bible. Louisville, (Kentucky: Westminster John Knox Press, 2009), h. 17-18.

3 Theodore of Mopsuestia, Commentary on Psalms 1-81, diterjemahkan oleh Robert C. Hill, Atlanta: Society of Biblical Literature, 2006, 85. Pemikiran ini berbeda dengan pandangan Martin McNamara yang setelah membahas pemikiran Theodore of Mopsuestia menyimpulkan bahwa Mazmur ini di satu sisi merupakan pengakuan 'Sang Prophet' kepada keagungan Allah yang memerintah seluruh yang ada di dunia, dan di sisi yang lain merupakan ucapan syukur kepada Sang Pencipta Agung atas apa yang dilakukan kepada manusia. lih. Martin McNamara, The Psalms in the Early Irish Church, (Sheffield: Sheffield Academic Press, 2000),h. 405.

${ }^{4}$ Lihat G. Sujin Pak, "Luther, Bucer, And Calvin On Psalms 8 And 16: Confessional Formation And The Question Of Jewish Execesis," Dutch Review of Church History / Nederlands Archief voor Kerkgeschiedenis", Vol. 85 Issue 1 (2005): 171.

5 Sebagaimana dikemukakan oleh Willem J. van Asselt dalam Willem J. van Asselt, "'Quid est homo quod memor es ipsius?" Calvin and Cocceius (1603-1669) on Psalm 8," Church History \& Religious Culture. Vol. 91 Issue 1/2 (Apr2011): h.140. Menurut Sujin Pak, Calvin memiliki interpretasi seperti ini, yang bertentangan dengan tradisi interpretasi yang umumnya (berkaitan dengan Kristus) ada terutama sampai dengan akhir abad pertengahan, karena membaca tafsiran Martin Bucer tentang Mazmur dan tafsiran Bucer ini mempengaruhi interpretasi Calvin atas Mazmur. Lih. G. Sujin Pak, "Luther, Bucer, And Calvin On Psalms 8 And 16," 170.

6 Bruce K. Waltke, James M. Houston and Erika Moore, The Psalms as Christian Worship. A Historical Commentary. (Grand Rapids, MI: Eerdmans, 2010), h. 244

7 Band. segitiga hirarki yang dipaparkan Carley dalam, Keith Carley, "Psalm 8: An Apology for Domination," dalam Readings from the Perspective of Earth, diedit oleh Norman C. Habel, (Sheffield: Sheffield Academic Press, 2000), h.114.

8 "The Letter Of Athanasius, Our Holy Father, Archbishop Of Alexandria, To Marcellinus On The Interpretation Of The Psalms," diakses terakhir 29 Januari 2014,

http://www.athanasius.com/psalms/aletterm.htm. Menurut Margaret Beirne, dalam pembahasannya terhadap interpretasi Athanasius atas Mazmur 8 ini, Mazmur 8 ini juga mengombinasikan antara situasi kekinian, suasana hati dan doa yang pantas dalam merespons karya Allah. Dengan mengungkapkan hal ini, Beirne memperlihatkan bahwa mengucap syukur atas karya Allah harus selalu menjadi kekinian, bukan sebuah peristiwa masa lampau, atau hanya (pernah) berlangsung sekali saja. Margaret Beirne, "St Athanasius and the Scriptures, Exemplified in His Letter to Marcellinus," Phronema. Vol. 28 Issue 2 (2013): 102. Sementara itu menurut Athanasius Mazmur 8 ini juga berhubungan dengan dengan anugrah Allah berupa penebusan. Dalam hal ini, menurut Waltke, Houston dan Moore, Athanasius mengikuti pemikiran Origenes. Bruce K. Waltke, James M. Houston and Erika Moore, The Psalms as Christian Worship, 245.

9 Sebagaimana dikemukakan Willem J. van Asselt dalam Willem J. van Asselt, "'Quid est homo quod memor es ipsius?", 140. Menarik bahwa menurut van Asselt, Calvin memakai Mazmur untuk menghubungkan situasi orang-orang Yahudi dalam Perjanjian Lama dengan 'orang-orang Reformasi’ yang juga mengalami tekanan dan ketidakadilan pada era Reformasi. Dan karena itu Calvin secara tidak langsung menyamakan pengalamannya dengan pengalaman Daud.

${ }^{10}$ Istilah kaki merupakan sebuah simbol yang penting di Mesir dan memiliki beberapa pemaknaan. Salah satu pemaknaannya berhubungan dengan kemampuan raja untuk menaklukkan musuhnya. Lih. Theological Dictionary of the Old Testament. Volume 13, u.k. "רֶֶֶֶ regel" diedit oleh G. Johannes Botterweck, Helmer Ringgren, Heinz-Josef Fabry, Grand Rapids, (Michigan: Wm. B. Eerdmans Publishing Co., 2004), h. 311.

${ }^{11}$ Johan H. Coetzee, "Yet Thou Hast Made Him Little Less than God": Reading Psalm 8 from a Bodily Perspective," dalam My Words are Lovely. Studies in the Rhetoric of the Psalms, diedit oleh Robert L. Foster dan David M. Howard Jr., (New York \& London: T \& T Clark International, 2008),h. 93.

${ }^{12}$ Erhard Gerstenberger, Psalms. Part 1: with an Introduction to Cultic Poetry, Grand Rapids, Michigan: 1988, 71. Interpretasi Gerstenberger ini menurut saya juga dapat ditunjukkan melalui pembacaan Mazmur 7. Mazmur ini, dan juga Mazmur 9, secara eksplisit memperlihatkan situasi pemazmur yang tertekan orang-orang yang dianggap memusuhinya. Mazmur ini juga secara jelas 
memperlihatkan keyakinan pemazmur bahwa hanya Allah-lah yang mampu menyelamatkan dia dari kejaran para musuhnya. Jadi Mazmur dapat dikatakan menjadi bukti atau jawaban atas keyakinan pemazmur ini.

13 Saya membatasi pemberian mandat ini hanya pada tanaman atau taman, tidak termasuk binatang, karena saya membedakan, secara latar belakang atau historis kritis, kisah penciptaan pada bagian ini, Kej. 2:8-25, berbeda dengan kisah penciptaan pada Kej. 1. Sampai dengan pemberian mandat pada Kej. 2:15 belum disebutkan tentang penciptaan binatang. Penciptaan binatang baru dimulai pada Kej. 2:19 dan dihubungkan dengan keinginan Tuhan Allah untuk menghadirkan penolong bagi manusia. Karena itu menurut saya pemikiran tentang dominasi manusia atas ciptaan yang lain seharusnya tidak didasarkan pada Kej. 2:15, karena dalam bagian ini manusia lebih dituntut tanggung jawabnya sebagai pelayan bagi ciptaan yang lain, ketimbang sebagai penguasa atas ciptaan yang lain.

14 Othmar Kiel, The Symbolism of the Biblical World. Ancient Near Eastern Iconography and the Book of Psalm, Winona Lake, Indiana: Eisenbraus, 1997, 58-59; lih. Juga Silvia Schroer dan Thomas Staubli, Body Symbolism in the Bible, Collegeville,( Minnesota: The Order of St. Benedict, Inc., 2001), h.192

${ }^{15}$ Theological Dictionary of the Old Testament. Volume 13, u.k. "רֶֶּ regel", 311.

16 Mazmur 145 biasanya digolongkan ke dalam 'Davidic' collection (koleksi Daud), sama seperti Mazmur 8, meskipun Mazmur ini dianggap berasal dari era sesudah pembuangan di Babel. Mazmur ini mendapat tempat penting bukan hanya dalam kehidupan orang yahudi tetapi juga dalam liturgi gereja. Lih. James Luther Mays, Psalms, Lousville, (Kentucky: Westminster John Knox Press, 2011), h.437.

${ }^{17}$ Nancy deClaissé-Walford, Rolf A. Jacobson dan Beth LaNeel Tanner, The Book of Psalm, Grand Rapids, (Michigan: Wm. B. Eerdmans Publishing Co., 2014),h. 120, 123-126.

18 Bandingkan doa syukur pemazmur ini dengan doa "Bapa Kami” yang diajarkan Yesus yang diawali dengan diawali dengan pengakuan akan kekudusan nama Tuhan dan 'jadilah kehendakMu di Bumi seperti di sorga" serta diakhir dengan "karena Engkaulah yang empunya kerajaan dan kuasa dan kemuliaan".

19 Film produksi tahun 2005 ini diangkat dari sebuah autobiografi yang berjudul: "How It Was with Dooms" yang ditulis oleh Xan Hopcraft, yang menjadi tokoh utama dari film ini, dan Carol Cawthra Hopcraft, ibunya.

20 Saya lebih memilih menyebut komunitas ini kelompok periferi dibanding kelompok minoritas. Penyebutan kelompok minoritas memberi kesan bahwa kelompok ini kecil jumlahnya dan belum perlu diberi perhatian. Gereja juga sering berpikir bahwa kelompok periferi ini jumlahnya kecil dalam gereja karena gereja tidak pernah melakukan studi atau pendataan berapa sebenarnya jumlah anggota kelompok ini dalam gereja. Saya lebih memilih memakai istilah kelompok periferi karena kelompok ini menyadari bagaimana sikap orang-orang di sekitar mereka umumnya, termasuk gereja, kepada mereka karena itu mereka cenderung kurang menonjolkan diri, terutama di dalam gereja. Mereka menjadi orang-orang yang cenderung ada di 'sisi luar' lingkungan masyarakat bahkan sisi luar gereja bahkan juga dengan sengaja dikesampingkan.

21 Secara saintifik pemanasan global adalah fenomena atmosfer bumi dalam melindungi bumi agar tetap hangat dengan menahan sebagian pantulan sinar inframerah matahari tetap di bawah selimut atmosfer bumi. istilah ini lebih tepat dikatakn sebagai efek rumah kaca. Lih. Mumu Muhajir dan Myrna A. Safitri, "REDD di Indonesia, kebijakan pemerintah dan kerentanan masyarakat: Sebuah pengantar," dalam REDD di Indonesia: Ke mana akan melangkah, diedit oleh Mumu Muhajir, (Jakarta: HuMA-Jakarta, 2010), h. 10.

22 Lih. Julie Kerr Casper, Greenhouse Gases. Worldwide Impacts, (New York:Facts On File, Inc., 2010), h.11-21.

23 Lih. "Cara Mengurangi Pemanasan Global," ArtikelLingkunganHidup.Com, diakses terakhir 1 Februari 2014, http://www.artikellingkunganhidup.com/cara-mengurangipemanasan-global.html. 


\section{DAFTAR PUSTAKA}

Artikel Lingkungan Hidup.Com. "Cara Mengurangi Pemanasan Global." Diakses terakhir 1 Februari 2014. http://www.artikellingkunganhidup.com/caramengurangi-pemanasan-global.html.

Athanasius Schaefer. 2013. "The Letter Of Athanasius, Our Holy Father, Archbishop Of Alexandria, To Marcellinus On The Interpretation Of The Psalms. "Diakses terakhir 29 Januari 2014". http://www.athanasius.com/psalms/aletterm.htm.

Barth, Marie Claire dan B. A. Pareira. 2009. Kitab Mazmur 1-72. Pembimbing dan Tafsirannya. Jakarta: BPK Gunung Mulia.

Beirne, Margaret. "St Athanasius and the Scriptures, Exemplified in His Letter to Marcellinus." Phronema. Vol. 28 Issue 2 (2013): 89-106.

Botterweck, G. Johannes, Helmer Ringgren dan Heinz-Josef Fabry (ed.). 2004. Theological Dictionary of the Old Testament. Volume 13 u.k, "regel". Grand Rapids, Michigan: Wm. B. Eerdmans Publishing Co.

Carley, Keith. 2000. "Psalm 8: An Apology for Domination," dalam Readings from the Perspective of Earth, diedit oleh Norman C. Habel, Sheffield: Sheffield Academic Press.

Casper, Julie Kerr. 2010. Greenhouse Gases. Worldwide Impacts. New York:Facts On File, Inc.

Coetzee, Johan H. 2008. "Yet Thou Hast Made Him Little Less than God": Reading Psalm 8 from a Bodily Perspective." dalam My Words are Lovely. Studies in the Rhetoric of the Psalms, diedit oleh Robert L. Foster dan David M. Howard Jr., 91-106. New York \& London: T \& T Clark International.

deClaissé-Walford, Nancy, Rolf A. 2014. Jacobson dan Beth LaNeel Tanner. The Book of Psalms, Grand Rapids. Michigan: Wm. B. Eerdmans Publishing Co.

Gerstenberger, Erhard. 1988. Psalms. Part 1: with an Introduction to Cultic Poetry. Grand Rapids, Michigan.

Mays, James Luther. 2009. Psalms. Lousville, Kentucky: Westminster John Knox Press.

McCann, J. Clinton Jr. 2009. Great Psalms of the Bible, Louisville. Kentucky: Westminster John Knox Press.

McNamara, Martin. 2000. The Psalms in the Early Irish Church. Sheffield: Sheffield Academic Press.

Theodore of Mopsuestia. 2006. Commentary on Psalms 1-81. diterjemahkan oleh Robert C. Hill. Atlanta: Society of Biblical Literature.

Muhajir, Mumu dan Myrna A. Safitri. 2010. "REDD di Indonesia, kebijakan pemerintah dan kerentanan masyarakat: Sebuah pengantar." Dalam REDD 
di Indonesia: Ke mana akan melangkah, diedit oleh Mumu Muhajir, 1-21. Jakarta: HuMA-Jakarta.

Pak, G. Sujin. "Luther, Bucer, And Calvin On Psalms 8 And 16: Confessional Formation And The Question Of Jewish Execesis." Dutch Review of Church History / Nederlands Archief voor Kerkgeschiedenis. Vol. 85 Issue 1 (2005).

van Asselt, Willem J. "'Quid est homo quod memor es ipsius?" Calvin and Cocceius (1603-1669) on Psalm 8." Church History \& Religious Culture. Vol. 91 Issue 1/2 (Apr2011).

Waltke, Bruce K. 2010. James M. Houston and Erika Moore, The Psalms as Christian Worship. A Historical Commentary. Grand Rapids, MI: Eerdmans. 